Palmer, T., Oberholzer, V. G., and Levin, B. (1974). Amino acid levels in patients with hyperammonaemia and argininosuccinic aciduria. Clinica Chimica Acta, 52, 335-341.

Roerdink, F. H., Gouw, W. L. M., Okken, A., Blij, J. F. van der, Luit-de Haan, G., Hommes, F. A., and Huisjes, H. J. (1973). Citrullinemia; report of a case, with studies on antenatal diagnosis. Pediatric Research, 7, 863-869.

Rogers, L. E., and Porter, F. S. (1968). Hereditary orotic aciduria. II. A urinary screening test. Pediatrics, 42, 423-428.

Thoene, J., Batshaw, M., Spector, E., Kulovich, S., Brusilow, S., Walser, M., and Nyhan, W. (1977). Neonatal citrullinemia: treatment with ketoanalogues of essential amino acids. Journal of Pediatrics, 90, 218-224.

\title{
Correspondence
}

\section{Sources of error in estimation of glomerular filtration rate from plasma creatinine concentration in children}

Sir,

Counahan et al. (1976) introduced a new simple method of estimating glomerular filtration rate (GFR) by means of plasma creatinine concentration $\left(P_{c}\right)$ and body height (Ht) using formula GFR (ml/min per $\left.1.73 \mathrm{~m}^{2}\right)=0.43 \mathrm{Ht}$ $(\mathrm{cm}) / \mathrm{P}_{\mathrm{c}}(\mathrm{mg} / 100 \mathrm{ml})$. Recently Szelid and Méhes (1977) showed in a large group of children without renal disease that the conventional 24-hour creatinine clearance correlates well with the GFR estimated by the $\mathrm{Ht} / \mathbf{P}_{\mathbf{c}}$ method. However the usefulness of the latter method demands that $\mathbf{P}_{c}$ be stable and that creatinine production be within normal limits, so that $P_{c}$ reflects only the excretory function of the kidneys.

Congenital nephrotic syndrome of Finnish type (CNF) is characterised by massive proteinuria, poor somatic growth, and slow deterioration of renal function (Hallman et al., 1973; Huttunen, 1977). On account of the decreased muscular mass in proportion to body weight, creatinine production and consequently $P_{c}$ of patients with CNF is low.

We have compared the GFR estimated by the $\mathrm{Ht} / \mathrm{P}_{\mathrm{c}}$ method with the 24-hour endogenous creatinine clearance (24-hour $C_{c}$ ) in 61 measurements of 15 CNF children under the age of 2 years, and in 67 children and young adults with acquired renal disease aged from 9 months to 20 years. Plasma and urinary creatinine were determined as true creatinine after absorption of noncreatinine chromogens by Lloyd's reagent (Henry et al., 1974). The results are shown in the Fig. The correlation between the two methods is satisfactory in both groups, but in CNF children the mean of the 24 -hour $C_{c}$ is $17.3 \mathrm{ml} / \mathrm{min}$ per $1.73 \mathrm{~m}^{2}$ lower than that of the GFR estimated by the $\mathrm{Ht} / \mathrm{P}_{\mathrm{c}}$ method; while in the children with acquired renal disease the 24-hour $\mathrm{C}_{\mathrm{c}}$ is $8.2 \mathrm{ml} / \mathrm{min}$ per $1.73 \mathrm{~m}^{2}$ higher than the result from the $\mathrm{Ht} / \mathrm{P}_{\mathrm{c}}$ method on average. The
Wick, H., Bachmann, C., Baumgartner, R., Brechbühler, T., Colombo, J. P., Wiesmann, U., Mihatsch, M. J., and Ohnacker, H. (1973). Variants of citrullinaemia. Archives of Disease in Childhood, 48, 636-641.

E. A. Burgess, V. G. Oberholzer, J. M. Semmens, and J. STERN

Queen Elizabeth Hospital for Children, London;

Southlands Hospital, Shoreham-by-Sea; and

Queen Mary's Hospital for Children, Carshalton.

Correspondence to Dr J. M. Semmens, Southlands Hospital, Upper Shoreham Road, Shoreham-by-Sea, Sussex BN4 6TQ.

mean of $P_{c}$ in CNF children was $0.41 \mathrm{mg} / 100 \mathrm{ml}(36.2$ $\mu \mathrm{mol} / \mathrm{l})$ with a range of $0 \cdot 16-1 \cdot 84 \mathrm{mg} / 100 \mathrm{ml} \mathrm{(14 \cdot 1-162 \cdot 7}$ $\mu \mathrm{mol} / \mathrm{l})$, and that of the children with acquired renal disease $0.69 \mathrm{mg} / 100 \mathrm{ml}(61 \mu \mathrm{mol} / \mathrm{l})$ with a range of $0 \cdot 26-7 \cdot 40 \mathrm{mg} / 100 \mathrm{ml}(23-654 \mu \mathrm{mol} / \mathrm{l})$. The 24-hour urinary excretion of creatinine per $\mathrm{kg}$ body weight of CNF children was $8 \cdot 6 \pm 2.5 \mathrm{mg}$ and that of the children with acquired renal disease $16 \cdot 5 \pm 4 \cdot 1 \mathrm{mg}$; the difference between the two groups is significant at the level of $\mathbf{P}<0.001$.

Creatinine is to some extent excreted by the renal tubular cells (Arant et al., 1972). Thus somewhat higher values are expected from the conventional 24-hour $\mathbf{C}_{c}$ than from the $\mathrm{Ht} / \mathrm{P}_{\mathrm{c}}$ method in children with normal creatinine production. On the other hand, in CNF children with low creatinine production the $\mathrm{Ht} / \mathbf{P}_{\mathrm{c}}$ method obviously overestimates the true GFR, and in this peculiar situation the conventional creatinine clearance is more accurate than the $\mathrm{Ht} / \mathrm{P}_{\mathrm{c}}$ method in the estimation of GFR. No doubt the $\mathrm{Ht} / \mathrm{P}_{\mathrm{c}}$ method is reliable and generally suitable to clinical work, but it must be remembered that it gives false results when $P_{c}$ is not in equilibrium or when the endogenous creatinine production is low.

\section{References}

Arant, B. S., Jr., Edelmann, C. M., Jr., and Spitzer, A. (1972). The congruence of creatinine and inulin clearances in children: use of the Technicon AutoAnalyzer. Journal of Pediatrics, 81, 559-561.

Counahan, R., Chantler, C., Ghazali, S., Kirkwood, B., Rose, F., and Barratt, T. M. (1976). Estimation of glomerular filtration rate from plasma creatinine concentration in children. Archives of Disease in Childhood, 51, 875-878.

Hallman, N., Norio, R., and Rapola, J. (1973). Congenital nephrotic syndrome. Nephron, 11, 101-110.

Henry, R. J., Cannon, D. C., and Winkelman, J. W. (1974). Clinical Chemistry. Principles and Technics, 2nd ed. Harper and Row, New York.

Huttunen, N-P. (1977). Creatinine clearance, urinary excretion of glomerular basement membrane antigens and renal histology in congenital nephrotic syndrome of Finnish 

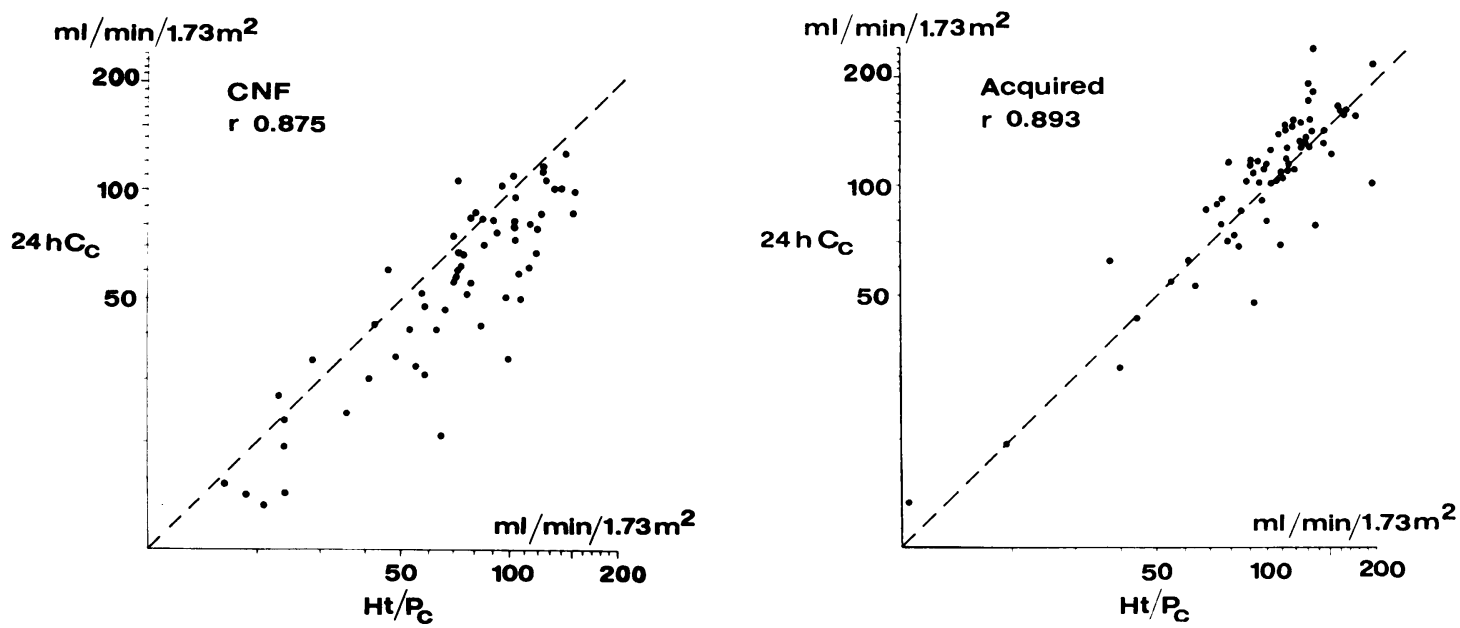

Fig. Correlation between 24-hour endogenous creatinine clearance (24-h $\left.C_{c}\right)$ and glomerular filtration rate estimated by the body height-plasma creatinine concentration method $\left(H t / P_{c}\right)$ in children with congenital nephrotic syndrome $(C N F)$ and in children with acquired renal disease.

type. Scandinavian Journal of Ciinical and Laboratory Investigation, 37, 133-138.

Szelid, ZS., and Méhes, K.(1977). Estimation of glomerular filtration rate from plasma creatinine concentration in children of various ages. Archives of Disease in Childhood, 52, 669-670.

Nillo-Pekka Huttunen, Maisa TaAlikka, and Ritva Metsola

Department of Paediatrics, University of Oulu, and

Children's Hospital, University of Helsinki, Finland.

\section{Nystatin resistance in thrush}

Sir,

Dr R. F. Jennison, in his useful review of thrush in infancy (Archives, 1977, 52, 747), did not mention the occurrence of nystatin resistance. In a recent case I was so impressed by the failure of nystatin, applied by an intelligent mother, to clear the perineal and oral thrush that I sent the baby with his thrush to the laboratory at the Sheffield Children's Hospital to have a culture made. There was a growth of Candida albicans resistant to nystatin (MIC $100 \mathrm{U} / \mathrm{ml}$ ), but sensitive to amphotericin B $(\mathrm{MIC}<\mathbf{0} \cdot 2 \mu \mathrm{g} / \mathrm{ml})$. The thrush cleared promptly with amphotericin.

R. S. ILLINGWORTH 8 Harley Road, Sheffield S11 9SD.

\section{European Congress of Obstetric Anaesthesia and Analgesia}

Sir,

It is intended to hold the first of what is hoped will become a sequence of congresses of this type at the National Exhibition Centre, Birmingham, England, in September 1979. The programme of the congress is designed to be of interest to anaesthetists, midwives, obstetricians, and paediatricians. Its major objective is to provide a forum whereby representatives of these specialities can discuss problems of mutual interest in respect to standards of safety and effectiveness of clinical practice, training, and staffing.

The congress will last for 4 days, and the general titles of the topics to be discussed are: (i) pain relief during labour; (ii) identification of, and supportive therapy for, the fetus at risk; (iii) anaesthesia for operative delivery; (iv) neonatal resuscitation; (v) intensive care of the seriously ill neonate; (vi) intensive care of the seriously ill parturient.

The meetings are being devised in such a way as to encourage the active participation of all delegates in th discussions which will follow each formal presentation. The prepared papers will be presented by anaesthetists, midwives, obstetricians, and paediatricians who are currently in practice in Europe. Simultaneous translation into English, French, and German will be available. A large trade exhibition will be sited within the congress hall, which will be of interest to all delegates. There will also be a full calendar of social events each day for delegates' nonparticipating companions and each evening for the entire company.

More detailed announcements will be forthcoming during the next few months. This preliminary notification is to enable interested readers to make a note of the dates (probably 18-21 September 1979) and, if they so wish, to write to me personally to request advance notice of the details of registration.

J. Selwyn Crawford

Chairman, Organising Committee, ECOAA The Birmingham Maternity Hospital, Queen Elizabeth Medical Centre, Edgbaston, Birmingham B15 2TG. 